\title{
English teaching material development as an alternative source in teaching English at junior high schools
}

Suwarni, Sri

Universitas Sebelas Maret, Indonesia (srisuwarni624@gmail.com)

Tarjana, Sri Samiati $\bowtie$

Universitas Sebelas Maret, Indonesia (msrisamiati@yahoo.com)

Slamet, St. Y

Universitas Sebelas Maret, Indonesia (slametsty@yahoo.co.id)

Ngadiso

Universitas Sebelas Maret, Indonesia (ngadisodok@yahoo.com)

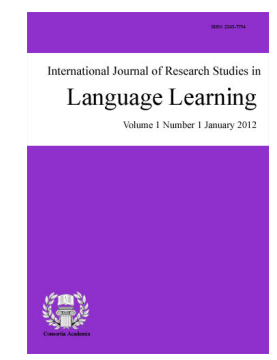

ISSN: 2243-7754 Online ISSN: 2243-7762

OPEN ACCESS

\section{Abstract}

The main purpose of this study was to develop an alternative teaching material for secondary school level that can improve learners' reading comprehension skill in English. There are three main steps in developing the teaching material. They are: need analysis, try out and experiment stage. In order to develop this book, a need analysis was conducted to know the need of the students regarding the teaching material that would be developed in this study. The study is conducted in 14 secondary schools. It was found that a Quantum Learning-based teaching material is suitable for the students. Some tries out were also done to complete and to perfect the model of the alternative teaching material. Then, an experimental stage is conducted to know whether the Quantum Learning-based teaching material is more effective than the old one. From data analysis, it is found that the mean of the students' result in reading comprehension using Quantum Learning-based teaching material is 79.48 and the one using old teaching material is 66.29. The mean is increasing by $19.89 \%$. So, the Quantum Learning-based teaching material is more effective than the old one.

Keywords: alternative teaching material; reading comprehension skill; Quantum Learning; material development; teaching reading skill 


\section{English teaching material development as an alternative source in teaching English at junior high schools}

\section{Introduction}

In this globalization era, human requires an ability to understand the reading on some different discourses. So that the information can be got quickly and accurately without difficulties by the language skill that still grows up. The main tool to deal with this era is the ability to get information which almost all of it is English. Baradja (1990) suggests that the reading ability is a primary capability in modern society and particularly in academic society. The ones who have not a good reading skill will have some difficulties in the developing their own selves, then they will find some difficulties in getting job.

In teaching process, the most vital element is how teachers can excite and engage students in learning, which in turn can encourage the students in achieving optimal learning outcomes. Teaching can be done to stimulate, guide, and entertain students with different approaches or methods of learning, where each approach can lead to the achievement of different learning objectives. But whatever the subject, teaching is essentially assist students in acquiring the knowledge, skills, attitudes, ideas, and appreciation, as well as attaining life skills that lead into changes in behavior and growth of students, including language skills which show someone's manner.

Teaching English is somehow the key of all educational activities related to human relations. The main objective of teaching modern languages in the education program is to encourage the development of the individual in society. One of skills in English is reading comprehension. Reading comprehension is one of skill taught in all schools. In general reading comprehension is reading which means to understand the content of a text. Reading ability which is taught in the schools are the ability to understand the contents of a text comprehensively either expressed or implied and express a variety of written speech read.

An important component in the teaching reading comprehension which has an important role in stimulating and increasing student activity is the use of teaching materials. In the process of teaching and learning reading comprehension, each reading material for students are expected to be accompanied by materials or instructional materials that aims to speed up the students' understanding of the texts studied. Herman (2001) in his paper presented in the International Conference of Indonesian Language Teaching Foreign Speakers (KIPBIPA) states that the criteria for teaching materials is a book. Unlike teaching materials which is a compilation, teaching materials in the form book would have outline which is more focused, has a systematic presentation, in addition, allows the students and the teachers are aware of the difficulty of learning. Thus, the standard of creating teaching materials in the form of book is that the book should fulfill the students' need, includes topics coherently, and considering the level of difficulty, especially grammatical difficulty level (graded grammar) to fulfill the needs of the student's ability to communicate properly.

In contrast with the criteria mentioned above, nowadays the book used by almost teachers of English has high level of grammatical. It may be because the authors focused their attention on the topic and communicative purpose only. There is also a book that is too concentrated in describing aspects of grammar that is less accommodating communicative purpose aspects. There was also a book that is too comprehensively describe the structure of the sentence, from the simplest one to most complex grammatical level, so it takes a long time to be able to communicate actively. Then, the researchers are interested in developing instructional teaching materials for reading comprehension skill. The teaching materials that will be developed is organized and also increase the national knowledge, which is presented to the nation's cultural diversity topics such as traditional musical instruments, dances and puppet characters. Although it is presented in that way, but the focus on sentence structure, from the simplest to the degree that has complex grammatical remains the same as something 
unforgotten.

\section{Related Literature}

\subsection{Reading Comprehension}

Reading as one skill taught to the students. It has very important role both at and outside school. Therefore, the development of language teaching reading skills for students of secondary level is also considered as a serious attention. Goodman and Olive (1980) explain that reading comprehension is a process of reconstructing the message contained in the text. Further, he said that it is a process of reconstructing the message that multi-layered, interactive, and a process of forming and testing hypotheses. Message is found through layers of meaning contained in the text. By interacting meaning contained in the text, the reader can make and test hypotheses, the results of hypothesis testing can be used as a basis to draw conclusions about the information conveyed by the message author. Nunan (1998) also states that the core of understanding is covered in one simple principle. Understanding is an attempt to build a new bridge between the known. An opinion that is rich and complex implications on the understanding of the process include: (1) understanding is active and not passive. Understanding is not merely a matter of recording and reporting is literally what he had read, (2) require a large amount of understanding of the decision-making, and (3) an understanding of a dialogue between authors and readers. There are some fundamental aspects of reading that was given in writing: (1) reading is interacting with the language set forth a written language, (2) the result of interaction with the form of written language comprehension, (3) the ability to read closely related to spoken language understanding and (4) to read an active and ongoing process that is directly influenced by the interaction between the individual and the environment.

\subsection{Quantum Learning}

There are many models of learning that can facilitate teachers perform key functions as learning agent. One of the well-known learning models is a model of Quantum Learning. Quantum Teaching is a body of knowledge and methodology used in the design, presentation, and facilitation in the Super Camp, an accelerated learning program method to learn the practice of Quantum Learning. The results shows that Quantum Learning can improve students' skills, increase their positive habit and also boosts their confidence (Vos Groenendal in DePorter \& Hernacki, 1992). The success of the method in the Super Camp makes some schools invite them to train teachers with this method. To fulfill the need broader, their training methods at Super Camp written in a book called Quantum Teaching, to be used by teachers in implementing learning in the classroom. So, it is the practice of Quantum Learning in the classroom. Simply put, Quantum Learning can be defined as learning that orchestrate interactions into light boost student achievement, by removing barriers to learning through the use of appropriate means and tools, so that students can learn easily and naturally. Quantum Learning is designed based on three things: the first principle, principles, and models (DePorter \& Hernacki, 1992).

Quantum Learning Principles - Quantum Learning consists of five principles, they are: 1) everything speaks, 2) everything is on purpose, 3) experience before label, 4) acknowledge every effort, and 5) if it's worth learning, it's worth celebrating (DePorter \& Hernacki, 1992). Everything speaks: all the things surrounding the learning situation, including teacher's intonation and the way of distributing of materials conveys an important message about learning. Thus, it is wise that teacher should consider everything related to teaching and learning. Everything is on purpose: Everything we do has an intended purpose. There is no action without clear and deliberate intentions, meaning that every action is done with a good intention, and it is always expected to gain good results. Experience before label: Students make meaning and transfer new content into long-term memory by connecting to existing schema. Learning is best facilitated when students experience the information in some aspect before they acquire labels for what is being learned. Acknowledge every effort: Acknowledgment of each student's effort encourages learning and experimentation. If it's worth learning, it's worth celebrating: Celebration provides feedback regarding progress and increases positive emotional associations with the 
learning.

\subsection{Teaching materials}

A teaching material is a mean of learning which function is as a main component of teaching learning. A teaching material can be presented in the form of book and non-book (audio visual), can be provided by an institution or can be made by the teacher (Richards, 2001). All those kinds of teaching materials are provided to be input by students in learning. For inexperienced teacher, teaching material can be used as a basis or a tool to develop a lesson plan or be used as a teaching design. A teaching material is closely related to learning system. Therefore, a teaching material is related to six learning components, they are: curriculum, objectives, syllabus, kinds and function of teaching material, teacher and students' role in teaching learning process, and relevance of the learning.

According to Richards (2001), there are three kinds of teaching materials, they are: 1) printed material which can be in the form of textbook, exercise book, and worksheet added with texts. 2) authentic and created teaching materials, it can be printed or non-printed material. For example: magazine, newspaper, internet, etc. and 3) non printed materials. It can be audio material like cassette, video, or computer-based material. The following explains about three kinds of materials; those are textbook, authentic, and compiled material, according to some experts.

As one of the forms of teaching materials, textbooks contained a good material can be used as an alternative substitution to a syllabus when the syllabus is not made in a good form. Even if the syllabus has been planned properly, supported by highly competent teacher, a good textbook is still needed (Dubin \& Olshtain, 1992). Teaching materials which is developed and packed in the form of book should not be separately develop in term of language skills. It has to be integrated. Teaching materials in the form of book often reflect the will of the author who sometimes ignores some other language skills and elements, which can be a disadvantage to students. To make a good teaching material, an author needs various considerations. Dubin and Olshtain (1992) mentions that the considerations include: (a) material are prepared by a team of developers who really understand the education system and the conditions of students, (b) the material is suitable with syllabus and procedures and techniques of teaching. If it is not, the materials still need to be improved; (c) teaching material in the form of textbook is an alternative source for teachers and students. It includes learner- tasks and learning styles, teaching techniques, and expected outcomes.

Further regarding the authentic teaching materials or created materials, it can be explained that in the process of teaching and learning, most teachers use instructional materials as the main source of learning. Instructional materials provide the content, integrated skills, and the kinds of practices do students. In planning learning programs, teachers can choose the type of materials that make use of authentic materials (authentic materials) or created materials (Richard, 2001). Authentic materials refer to the use of text, photos, videos, and other learning resources that real or not specifically designed for teaching. Created materials refer to textbooks and other learning resources are specifically designed for teaching materials (Richards, 2001). Pertaining to teaching materials, most people argue that authentic materials are preferred than the created materials. Because the authentic teaching materials contain authentic language and have better way in using real language when it is compared to materials that have less concern about real thing in the students' surrounding. In line Richards, Cunningsworth (1995) states that authentic material refers to authentic content. This type of teaching materials are taken based on facts or actual phenomenon instead of a made-up content called created teaching materials by Richards (2001). The language used in authentic content can be authentic, semi-authentic (simplified), or written specifically, depending on the level of the students. Although the authentic teaching materials tend to be preferred because it has many advantages, but the type of material has also advantages and disadvantages.

In addition to these two types of instructional materials for learning, as described above, Cunningsworth (1995) describes the type of other material which called compiled teaching material. Compiled teaching material 
English teaching material development as an alternative source in teaching English at junior high schools

are teaching materials that are obtained by compile existing materials, making it more suitable for particular students, teachers, or a specific learning environment. In preparing the teaching learning process, the teacher may decide to use only some unit, add or delete text or activities, replace the text or activity taken from other sources. These materials can be changed flexibly to adjust the students. The compiled teaching is used because the teacher unsuitable with some things. The inconveniences include: (a) teaching environment (national, regional, institutional, cultural, and so on), for example, the material has not been designed for the local cultural background, (b) their students (age, level of understanding, previous learning experiences, learning styles, and etc.), (c) preferences (personality, teaching style, his ability to learning), for example, the material offers too many communicative activities but teachers are worried about losing control during implementation; (d) learning objectives (syllabus, learning targets, and etc.), for example, the focus of teaching materials available is on learning grammar but specific learning objectives focused on developing students' communication strategies, (e) teaching materials (texts, tasks, activities), such as text interesting but the activity is boring and does not appear to exploit the text (Cunningsworth, 1995).

\section{Research Design}

This study belongs to Research and Development (R\&D). Borg and Gall (2003) defines R\&D as a process to develop and validate educational products. Some common products developed in R\&D are a variety of teaching tools such as curriculum, syllabus, learning modules, including teaching materials. There are many researches that have been conducted on creating syllabus design, lesson plan and teaching method. However, this research is a research development. It develops alternative teaching materials that can be used by teachers in increasing reading comprehension skills of their student. Consequently, the need analysis has to be done to collect some information related to kind of teaching material needed by the students. In particular, the purpose of the research will be to create a teaching material that is based on the students' need and has effective influence to them.

It is expected that the result of this research may provide practical information about the effectiveness of alternative teaching materials, as well as contribute to the exiting teaching material. It is also expected that the result of this research can provide a help for the authority of curriculum to consider the implementation of alternative teaching material for teaching reading.

The specific research questions in this study are:

What kind of teaching material should be developed in order to increase reading comprehension skill?

$>$ Is the developed teaching material more effective than the old one?

\subsection{Research Method}

In developing the teaching material, the author used a research and development method. As suggested by Gall, Borg, and Gall (2003), research and development is a process in developing and validating educational product. Gall, Borg \& Gall (2003) also state that the steps of research and development are: (1) research analysis, needs assessment and proof of concept; (2) product planning and design; (3) preliminary product development; (4) preliminary field testing; (5) product revision; (6) main field testing; (7) and the final product revision and dissemination. In this study the author used those steps implemented in three stages, they are:

Preliminary research - In this stage, the author looked for some data related to the teaching material and also interviewed teachers and students about the teaching materials they used. From the data, the author knew the condition and the situation of the use of teaching material used by the teachers and the students. Then, the author made some conclusion based on the data about the teaching material.

Model development - From a preliminary research, it is stated that the author made some conclusions. In this stage, after the author made the conclusion, the author did a need analysis and made a prototype of the 
teaching material that is suitable with the teachers and the students. So, the first product was a prototype of the teaching material. Next, the prototype was tried out in some schools. It was supposed to give any description of the use of the prototype. After that, author did some reflections to perfect and complete the teaching material. So, the product of model development was an advanced prototype which was different with the first prototype.

Experiment - In experiment stage, there were two schools used by the author. In those two, the author did an experiment research. In each school, there were two groups. The first group was called control group and the second was experiment group. Both groups were taught for 4 weeks by using different treatment. The first group was thought by using old teaching material and the second was thought by using developed teaching material. Before the treatment, the students were tested called pretest and after the treatment the students were also tested called posttest. The result of posttest was used to give a conclusion whether the developed material is more effective than the old one.

\subsection{Settings}

This study was conducted in fourteen junior high schools. These fourteen junior high schools were chosen because those schools are suitable with the research aims and they provide information needed by the research. The schools are: (1) SMP N 1 Sayung Demak, (2) SMP N 3 Demak, (3) SMP N 4 Demak, (4) SMP N 5 Demak, (5) SMP N 1 Karang Tengah Demak, (6) SMP N 1 Bonang Demak, (7) SMP N 1 Wonosalam Demak (8) SMP N 1 Mijen Demak, (9) SMP N 1 Gajah Demak, (10) MTs NU Demak, (11) MTs Al-Irsyad Gajah Demak.(12) SMP N 2 Demak, (13) MTs Negeri Karang Tengah, (14) SMP N 1 Demak

\subsection{Data Collection}

There are two kinds of data in this research. They are qualitative and quantitative data. The data were collected by the following instruments:

$>$ Interview of 14 teachers in each fourteen about teaching and learning process of English was done.

$>$ Some observations for each lesson were noted. From this observation, the author perfect and complete the prototype of the teaching learning material in 'try out' stage.

$>$ A test was conducted in experiment stage to know whether the new teaching material is more effective than the old one. The test is conducted with 60 items of questions. And 10 questions are out after content validity is done (Crocker \& Algina, 1986). Thus, the valid items are 50. Besides, the reliability is done with SPSS and achieved Cronbach's alpha 0.73. It can be said that the reliability is good.

\subsection{Significance of the Study}

There have been some research attempts (Sunarti, 2003; Hermayawati, 2008; Yoon, 2012; Vaes Dalili \& Tavakoli, 2013), to name a few, aimed at exploring the strategy of teaching reading. However, in a very few of them (see, e.g., Hermayawati, 2008) researchers have tried to develop teaching materials to teach reading. Thus, finding of more studies in the field, especially, regarding to developing English teaching materials will hopefully result in increasing the students' skill in reading English.

\section{Result and Discussion}

In this study, the data for analysis include the interview, field note of classroom observation and results of teaching learning process from the students. The author conducted the interview with the teacher both in Bahasa and English. The author also decided to present the data in a form of short quotes about the focus of this study. For the teachers who use Bahasa, it will be translated in English but retained its original idea. 


\subsection{Preliminary Study}

Results of this preliminary study are obtained mostly through observation and interview the teachers at the junior high school students. The analysis was conducted in fourteen junior. They are (1) SMP N 1 Sayung Demak, (2) SMP N 3 Demak, (3) SMP N 4 Demak, (4) SMP N 5 Demak, (5) SMP N 1 Karang Tengah Demak, (6) SMP N 1 Bonang Demak, (7) SMP N 1 Wonosalam Demak (8) SMP N 1 Mijen Demak, (9) SMP N 1 Gajah Demak, (10) MTs NU Demak, (11) MTs Al-Irsyad Gajah Demak. (12) SMP N 2 Demak, (13) MTs Karang Tengah, (14) SMP N 1 Demak. In those fourteen junior high schools, the author interviewed the teachers and some students in each school. The interview was about the use of the teaching materials they used in teaching and learning process of English.

Almost all the teaching materials are suitable with the syllabus the purpose of learning. It was explained by some teachers, such as teachers from SMP N 5 Demak and MTs NU Demak. In the following excerpt, a teacher of SMP N 5 Demak and MTs Nu Demak stated about the teaching material and syllabus:

...the teaching material I use has a good quality in term of the suitability with a syllabus I use (SMP N 5 Demak, Jan $17^{\prime}$ '12)

There is no problem with a teaching material, because it is already contains the syllabus (MTs NU Demak, Jan 20 '12)

They stated that the teaching material they use is suitable with the syllabus. In line with that idea, a teacher from SMP N 2 Demak, she stated:

...teaching material I use, is not too far from the syllabus ... (SMP N 2 Demak, Jan 23 '12)

Next interview was about the appearance and the steps found in the teaching materials. Related to the appearance, the majority of the teacher said that the teaching materials they use have a bad/ common appearance. That makes the students are easy to be bored because they see the same appearance from time to time. Teachers from SMP N 1 Demak, SMP N 4 Demak, and SMP N 1 Mijen Demak have some opinions

...my students are usually bored when facing the evaluation and the same look of the teaching material (SMP N 4 Demak, Jan 17 '12)

The familiar appearance makes the students feel bored... (SMP N Mijen Demak, Jan 24 '12)

The other weakness of the teaching materials was about the evaluation. The evaluation found in their teaching material was seemed to force the students that make the students reluctantly in doing the tasks. It was explained by teachers from MTs N Karang Tengah and SMP N Karang Tengah.

The students feel not good and as a teacher, it's like I have to force them to do the evaluation. (MTs N Karang Tengah, Jan 19 '12)

... and it is not comfortable to force them doing what they're not interested in. (SMP N Karang Tengah, Jan 19'12)

It can be stated that the evaluation is like forcing the students. The other opinion about the evaluation was from teacher of SMP N 3 Demak. She stated that the evaluation is less of variation.

It's not vary and boring. (SMP N 3 Demak, Jan 20 ’12)

From the above results, the authors found two main problems in the teaching materials i.e. the appearance and steps in delivering material and the kind of evaluation. 


\subsection{Model Development}

The next stage, after preliminary study, is model development. In the first stage, preliminary study, it is found that teaching materials that are used by the teachers have some weaknesses such as, it were not suitable with the students' need and were not interesting for the students. From the results of preliminary study, the author did a need analysis of the students. After doing the analysis, the author creates a prototype that supposed to be working with the students' need and to be suitable with them. So, the first product of the research was prototype.

Then, the next is expert judgment. The prototype created by the author was consulted to the experts of English language learning and technology of education. From the experts, they suggested that the author had to use a certain method in delivering the material. Then, it was decided that Quantum Learning-based teaching materials was the more suitable method and kind of teaching material that is suitable with the students and teachers. The experts and the teachers agreed that the teaching material use the following procedure, i.e. Enroll, Experience, Labeling, Demonstration, Review and Celebration (EEL Dr. C). The procedure descriptions are: $\mathrm{E}=$ Enrollment, the teaching material should attract the interests of students before entering the material; (b) $\mathrm{E}=$ Experience, the teaching material gives real/ direct experience direct that suitable with students before the presentation; (c) $\mathrm{L}=$ Labeling, the teaching material gives name about something that has been experienced by the students; (d) D = Demonstration, it means the teaching material gives a chance to the students to demonstrate what they have learned; (e) $\mathrm{R}=$ Review, it is the repetition of what have learned; and (e) $\mathrm{C}=$ Celebration, it is a time when the students get a reward because they achieve something by using words or pictures.

After the judgment from the expert and some suggestion from the teachers, the author did some tries out. The tries out was aimed to perfect and make some modification to a better teaching material. It was done by trying out the prototype in 12 junior high schools. The author or teachers tried to use the teaching material and make a note about what happen in the teaching and learning process. The note is about the weakness and the strengths of the teaching materials. In those tries out, it was found that the teaching material needed an additional media for students to an individual use. Then, the author made an interactive flash media. Besides, the author also made some modification in evaluation, enrollment that was more suitable with the students. After all activities in model development, such as, need analysis, expert judgment, and some tries out, the author had a model/ prototype that was visible and ready to be experimented.

\subsection{Experiment}

The last stage was experiment stage. This stage was aimed to test the effectiveness of the teaching material which had been considered visible. The experiment was conducted in two junior high schools. They were MTs Negeri Karang Tengah and SMP N 1 Demak. The experiment was conducted in two groups for each school. The first group is called experiment group and the other is control group. Experiment group was taught by using the alternative teaching material developed and the control group was taught by the old teaching material. The results of the treatments were indicated by test. There were two tests done by the author to know the effectiveness of the teaching material. The first test was pretest conducted before the treatment while the second was posttest conducted after the treatment.

From the analysis of the data, it is found that the average of the students in experiment group after using quantum learning-based teaching materials is 79.48, while those students in control group who used the old teaching material is 66.29 , so there is an increasing mean of $19.89 \%$. Then after being tested with a statistical hypothesis testing, there is a significant different between the students' result in learning by using the developed teaching material and by using the old teaching material. Thus, it can be concluded that the quantum learning-based teaching materials is more effective than the old book.

Here are the results of the experiment stage: 
English teaching material development as an alternative source in teaching English at junior high schools

Table 1

Table of the result of the experiment stage in SMP N 1 Demak

\begin{tabular}{|c|c|c|c|c|c|c|}
\hline \multirow{2}{*}{ NO } & \multirow{2}{*}{ Initial } & \multicolumn{2}{|c|}{ Control group } & \multirow{2}{*}{ Initial } & \multicolumn{2}{|c|}{ Experiment group } \\
\hline & & Pretest & Posttest & & Pretest & Posttest \\
\hline 1 & B1 & 66 & 78 & D1 & 64 & 80 \\
\hline 2 & B2 & 64 & 76 & D2 & 62 & 80 \\
\hline 3 & B3 & 58 & 50 & D3 & 60 & 90 \\
\hline 4 & B4 & 52 & 70 & D4 & 54 & 80 \\
\hline 5 & B5 & 44 & 70 & D5 & 44 & 70 \\
\hline 6 & B6 & 42 & 60 & D6 & 44 & 80 \\
\hline 7 & B7 & 58 & 60 & D7 & 60 & 70 \\
\hline 8 & B8 & 72 & 60 & D8 & 68 & 60 \\
\hline 9 & B9 & 68 & 80 & D9 & 70 & 80 \\
\hline 10 & B10 & 68 & 80 & D10 & 66 & 70 \\
\hline 11 & B11 & 76 & 60 & D11 & 74 & 80 \\
\hline 12 & B12 & 56 & 70 & D12 & 56 & 80 \\
\hline 13 & B13 & 72 & 60 & D13 & 72 & 80 \\
\hline 14 & B14 & 72 & 60 & D14 & 68 & 80 \\
\hline 15 & B15 & 34 & 80 & D15 & 40 & 80 \\
\hline 16 & B16 & 60 & 30 & D16 & 60 & 80 \\
\hline 17 & B17 & 72 & 70 & D17 & 70 & 80 \\
\hline 18 & B18 & 56 & 60 & D18 & 56 & 60 \\
\hline 19 & B19 & 52 & 70 & D19 & 58 & 60 \\
\hline 20 & B20 & 72 & 60 & D20 & 72 & 70 \\
\hline 21 & B21 & 72 & 50 & D21 & 76 & 80 \\
\hline 22 & B22 & 58 & 60 & D22 & 58 & 60 \\
\hline 23 & B23 & 60 & 80 & D23 & 60 & 90 \\
\hline 24 & B24 & 60 & 70 & D24 & 60 & 80 \\
\hline 25 & B25 & 48 & 50 & D25 & 50 & 70 \\
\hline 26 & B26 & 68 & 60 & D26 & 70 & 70 \\
\hline 27 & B27 & 64 & 40 & D27 & 62 & 90 \\
\hline 28 & B28 & 72 & 70 & D28 & 70 & 90 \\
\hline 29 & B29 & 68 & 60 & D29 & 70 & 60 \\
\hline 30 & B30 & 76 & 80 & D30 & 78 & 70 \\
\hline 31 & B31 & 64 & 66 & D31 & 68 & 80 \\
\hline 32 & B32 & 60 & 60 & D32 & 62 & 90 \\
\hline 33 & B33 & 78 & 80 & D33 & 80 & 60 \\
\hline 34 & B34 & 60 & 60 & D34 & 62 & 70 \\
\hline 35 & B35 & 62 & 60 & D35 & 60 & 80 \\
\hline
\end{tabular}

\section{Conclusion and implications}

The result shows that a Quantum Learning-based teaching material is suitable with the students' needs. Moreover, from the analysis of the data, it is found that the average of the students in experiment group after using quantum learning-based teaching materials is 79.48 , while those students in control group who used the old teaching material is 66.29 , so there is an increasing mean of $19.89 \%$. Thus, it can be concluded that the quantum learning-based teaching materials is more effective than the old book.

The results of this study make a few implications and suggestions for language teaching.

$>$ The local authority of EFL curriculum should consider the implementation of Quantum Learning teaching material as one of teaching material for teaching reading.

$>$ In developing or choosing English teaching material, local educators should consider how the materials suit the students' characteristics. The local educators must join more seminar or workshop about how to develop English teaching material, so they can develop their materials and adjust their students' characteristics. 
Suwarni, S., Tarjana, S. S., Slamet, S. T., \& Ngadiso

$>$ For teachers, the teaching material can be used to teach reading. The teachers are also able to improve the material according to the students.

For learners, the teaching material can help them to learn and improve their reading skill. They can use it individually.

Table 2

Table of the result of the experiment stage in SMP N 1 Karang Tengah

\begin{tabular}{|c|c|c|c|c|c|c|}
\hline \multirow{2}{*}{ No } & \multirow{2}{*}{ Initial } & \multicolumn{2}{|c|}{ Control group } & \multirow{2}{*}{ Initial } & \multicolumn{2}{|c|}{ Experiment group } \\
\hline & & Pretest & Posttest & & Pretest & Posttest \\
\hline 1 & A1 & 76 & 80 & B1 & 80 & 70 \\
\hline 2 & A2 & 68 & 70 & B2 & 68 & 80 \\
\hline 3 & A3 & 78 & 80 & B3 & 76 & 80 \\
\hline 4 & A4 & 70 & 70 & B4 & 66 & 90 \\
\hline 5 & A5 & 68 & 70 & B5 & 69 & 90 \\
\hline 6 & A6 & 70 & 70 & B6 & 72 & 80 \\
\hline 7 & A7 & 72 & 70 & B7 & 70 & 70 \\
\hline 8 & A8 & 68 & 70 & B8 & 70 & 90 \\
\hline 9 & A9 & 64 & 66 & B9 & 66 & 86 \\
\hline 10 & A10 & 68 & 68 & B10 & 64 & 80 \\
\hline 11 & A11 & 64 & 80 & B11 & 60 & 90 \\
\hline 12 & A12 & 68 & 66 & B12 & 64 & 78 \\
\hline 13 & A13 & 68 & 60 & B13 & 70 & 80 \\
\hline 14 & A14 & 65 & 80 & B14 & 68 & 90 \\
\hline 15 & A15 & 56 & 60 & B15 & 58 & 82 \\
\hline 16 & A16 & 62 & 60 & B16 & 60 & 76 \\
\hline 17 & A17 & 60 & 80 & B17 & 62 & 90 \\
\hline 18 & A18 & 34 & 70 & B18 & 68 & 86 \\
\hline 19 & A19 & 60 & 80 & B19 & 76 & 80 \\
\hline 20 & A20 & 65 & 70 & B20 & 72 & 88 \\
\hline 21 & A21 & 56 & 70 & B21 & 54 & 78 \\
\hline 22 & A22 & 52 & 70 & B22 & 60 & 80 \\
\hline 23 & A23 & 72 & 70 & B23 & 70 & 86 \\
\hline 24 & A24 & 72 & 70 & B24 & 79 & 86 \\
\hline 25 & A 25 & 64 & 66 & B25 & 66 & 80 \\
\hline 26 & A26 & 72 & 68 & B26 & 74 & 80 \\
\hline 27 & A 27 & 68 & 80 & B27 & 74 & 84 \\
\hline 28 & A28 & 74 & 50 & B28 & 73 & 70 \\
\hline 29 & A29 & 64 & 60 & B29 & 66 & 80 \\
\hline 30 & A30 & 60 & 80 & B30 & 64 & 90 \\
\hline 31 & A31 & 72 & 70 & B31 & 70 & 80 \\
\hline 32 & A32 & 60 & 50 & B32 & 62 & 74 \\
\hline 33 & A33 & 62 & 60 & B33 & 64 & 70 \\
\hline 34 & A34 & 64 & 40 & B34 & 62 & 70 \\
\hline
\end{tabular}

\section{References:}

Baradja, M. F. (1990). Capita Selekta in language teaching [Kapita selekta pengajaran bahasa]. Malang: IKIP Malang.

Crocker, L., \& Algina, J. (1986). Introduction to classical and modern test theory. Orlando, Florida: Holt, Rinehart and Winston, Inc.

Cunningsworth, A. (1995). Choosing your course book. Great Britain: The Bath Press.

DePorter, B., \& Hernacki, M. (1992). Quantum Learning: Unleasing the genius in you. New York: Dell Publishing.

Dubin, F., \& Olshtain, Elite. (1992). Course design developing programs and materials for language learning. Cambridge: Cambridge University Press. 
English teaching material development as an alternative source in teaching English at junior high schools

Gall, J., Borg. W., \& Gall, M. (2003). Educational research: An introduction (7th Ed.). Boston: Pearson.

Goodman, K. S., \& Niles, O. S. (1980). Reading process and program. Illinois: Commission on the English Curriculum National Council of Teachers of English.

Herman, E. (2001). Topical teaching material and steps of difficulties: LIA Bahasa Indonesia program [Bahan Ajar yang Bertopik dan Bertingkat Kesulitan Runtut. Program Bahasa Indonesia LIA]. Paper presented at the International Conference of Indonesian Language Teaching Foreign Speakers (KIPBIPA).

Hermayawati. (2008). English teaching material development with functional approach (a developmental research in PJTKI Jakarta) [Pengembangan Materi Ajar Bahasa Inggris dengan Pendekatan Fungsional (Penelitian Pengembangan di PJTKI Jakarta)]. Unpublished doctoral dissertation, Universitas Sebelas Maret, Surakarta.

Nunan, D. (1998). Principles of communication task design, in Das, Bingram k. materials for language learning and teaching. Singapore: SEAMEO Regional Language Center.

Richards, J. C. (2001). Curriculum development in language teaching. Cambridge: Cambridge University Press. http://dx.doi.org/10.1017/CBO9780511667220

Sunarti. (2003). The effect of test and text types in increasing Result of Reading Comprehension Learning in Junior High School [Pengaruh Bentuk Latihan dan Jenis Teks Terhadap Peningkatan Hasil Belajar Membaca Pemahaman Siswa SLTP]. Unpublised thesis, Universitas Negeri Malang, Malang.

Vaes Dalili, M., \& Tavakoli, M. (2013). A comparative analysis of reading strategies across ESP students of humanities and engineering. International Journal of Research Studies in Language Learning, 2(5), 63-78.

Yoon, T. (2012). Beyond the traditional reading class: The application of an e-Book in EFL English classroom. International Journal of Research Studies in Language Learning, 2(1), 17-26. 
Suwarni, S., Tarjana, S. S., Slamet, S. T., \& Ngadiso 